\title{
A case of bladder diverticulum simulating ovarian cyst during pregnancy
}

\author{
Anjali Rani*, M. Matah
}

\begin{abstract}
Department of Obstetrics \& Gynaecology, Institute of Medical Sciences, Banaras Hindu University, Varanasi-221005
\end{abstract} Uttar Pradesh, India

Received: 10 June 2014, Revised: 29 June 2014

Accepted: 1 July 2014

\section{*Correspondence:}

Dr. Anjali Rani,

E-mail: anjaliraniimsbhu@gmail.com

(C) 2014 Rani A et al. This is an open-access article distributed under the terms of the Creative Commons Attribution Non-Commercial License, which permits unrestricted non-commercial use, distribution, and reproduction in any medium, provided the original work is properly cited.

\begin{abstract}
33 year old female G3P2+0 at 32 weeks of gestation was admitted in labour room with the complain of pain abdomen and difficulty in passing urine. On examination vitals were stable. Abdominal examination there was cystic swelling in suprapubic region extending up to umbilical region. Uterus was 32 week size. Report of USG from peripheral centre showed ovarian cyst. We made a provisional diagnosis of twisted ovarian cyst. Exploratory laparotomy was done there was no ovarian cyst and bladder diverticulum was present. Urologist called and first he aspirated fluid and it was urine. Then while separating the swelling from uterus bladder opened and resected the diverticulum. Bladder was sutured. Abdomen was closed. Patient went into preterm labour and delivered vaginally single live female of 2.1 $\mathrm{kg}$ weight. Postoperative period was uneventful. Patient was lost in follow up.
\end{abstract}

Keywords: Bladder diverticulum, Pregnancy, Ovarian cyst

\section{INTRODUCTION}

Diverticulum of bladder is herniation of mucosa and submucosa from bladder muscular wall. Normally they are asymptomatic. They can be congenital or acquired. They are caused by weakening the bladder muscular fibres. $^{7,8}$ They usually occurs in males. Congenital bladder diverticulum is sometime associated with congenital connective tissue disorder. Acquired diverticula are usually multiple and associated with bladder outlet obstruction. Sometime they can mimic an ovarian cyst. In our case patient presented with lump in abdomen and acute pain abdomen and USG was showing ovarian cyst. But on laparotomy it was a giant bladder diverticulum.

\section{CASE REPORT}

33 year old female $\mathrm{G} 3 \mathrm{P} 2+0$ at 32 weeks of gestation was admitted in labour room with the complain of pain abdomen and difficulty in passing urine. On examination hydration was normal. Blood pressure and pulse rate was normal. No lymphadenopathy and mild pedal oedema was present. Mild pallor was present. On doing abdominal examination uterus was 32 week size and FHS was $140 /$ minute regular. There was a cystic swelling was present in suprapubic region extending up to umbilical region. Patient was catheterized but there was only small $(10 \mathrm{ml})$ amount of urine drained. Patient was given injection betnesol $12 \mathrm{mg}$. Patient showed report of Ultrasound from a peripheral centre which diagnosed it as ovarian cyst.

Exploratory laparotomy done and it was a big bladder diverticulum and no ovarian cyst. Urologist identified it as bladder diverticulum. Needle was put inside and the fluid aspirated was urine. Then while separating the swelling from uterus bladder opened and resected the nonfunctional part of bladder wall. Bladder was sutured. Abdomen was closed. Antibiotics were given. In postoperative period this patient went into preterm labour 
and delivered a female baby at 33 weeks and weighing $2.1 \mathrm{~kg}$. In follow up both mother and baby were fine.

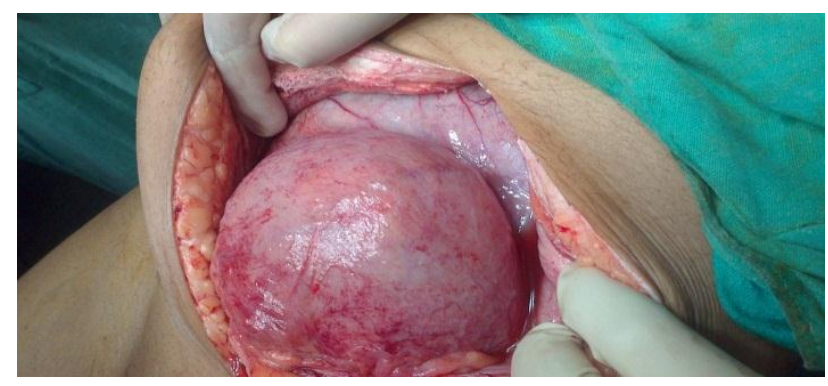

Figure 1: Laparotomy: bladder diverticulum-1.

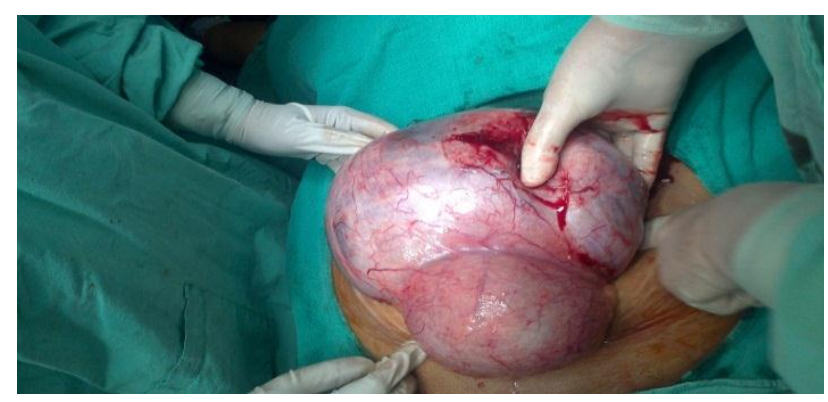

Figure 2: Laparotomy: bladder diverticulum-2.

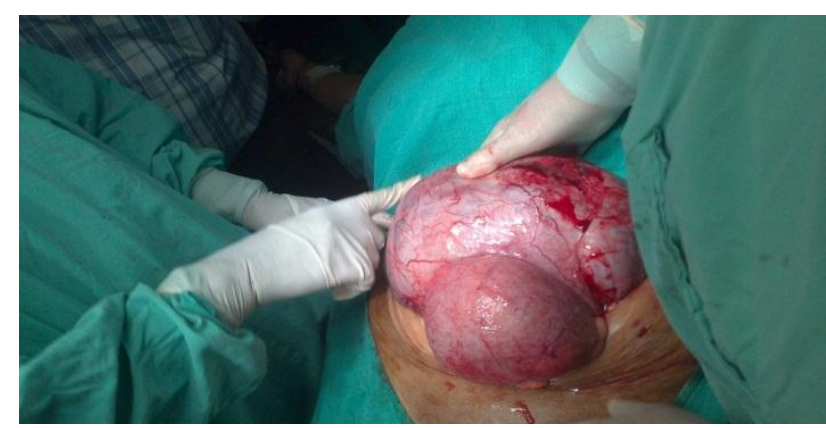

Figure 3: Laparotomy: bladder diverticulum-3.

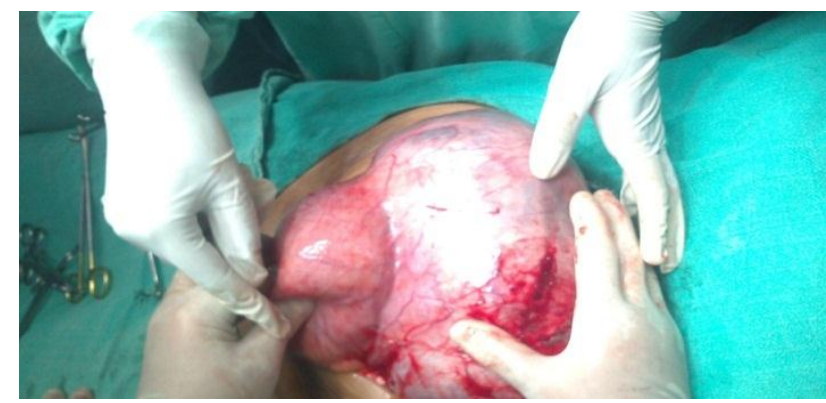

Figure 4: Laparotomy: bladder diverticulum-4.

\section{DISCUSSION}

In this case report pregnant patient with pain abdomen with ovarian cyst in ultrasound made us to do laparotomy. We should have done a repeat USG and differential diagnosis of bladder diverticulum should be kept in mind. We were misled because after catheterization no urine came and the size of cystic swelling did not decreased. So we thought it can be a twisted ovarian cyst. This has led to futile laparotomy.

Funding: No funding sources Conflict of interest: None declared

Ethical approval: Not required

\section{REFERENCES}

1. Weingardt JP, Nemcek AA Jr, Miljkovic SC. The diverticular jet effect: color Doppler differentiation of bladder diverticulum from other pelvic fluid collections. J Clin Ultrasound. 1994;22:397-400.

2. Levine D, Filly RA. Using color Doppler jets to differentiate a pelvic cyst from a bladder diverticulum. J Ultrasound Med. 1994 Jul;13(7):5757.

3. Farhi J, Dicker D, Goldman JA. Giant diverticulum of bladder simulating ovarian cyst. Int J Gynaecol Obstet. 1991;36:55-7.

4. Wang CW, Chang YL, Horng SG, Chueh HY, Soong YK, Chiu HC. Pitfalls in the differential diagnosis of a pelvic cyst: lessons from a postmenopausal woman with bladder diverticulum. Int J Clin Pract. 2004 Sep;58(9):894-6.

5. Kruse A J, Bakers FC, Kruitwagen RF. Diverticulum of the bladder simulating ovarian cyst: Pitfalls in the differential diagnosis. JBR-BTR. 2011 SeptOct;94(5):300.

6. Soo-Cheen $\mathrm{Ng}$, Sung-Lang Chen, Gin-Den Chen. Bladder diverticula in a young woman: congenital or acquired? Incont Pelvic Floor Dysfunct. 2011;5(2):43-5.

7. Garat JM, Angerri O, Caffaratti J, Moscatiello P, Villavicencio $H$. Primary congenital bladder diverticula in children. Urology. 2007;70:984-8.

8. Walsh PC. Diverticulum of bladder. In: Meredith F. Campbell, Patrick C. Walsh, Alan B. Retik, eds. Campbell's Urology. 8th ed. Philadelphia: Saunders; 2002: 2188-2189.

DOI: $10.5455 / 2320-1770 . i j r \operatorname{cog} 20140923$

Cite this article as: Rani A, Matah M. A case of bladder diverticulum simulating ovarian cyst during pregnancy. Int J Reprod Contracept Obstet Gynecol 2014;3:785-6. 